\title{
0681. Effects of veno-venous co2 removal therapy on pulmonary circulation in an ARDS model
}

\author{
P Morimont ${ }^{1,2^{*}}$, T Desaive ${ }^{2}$, J Guiot ${ }^{1}$, V Tchana-Sato ${ }^{1}$, N Janssen ${ }^{1}$, A Cagnina ${ }^{1}$, S Habran ${ }^{2}$, S Kosta ${ }^{2}$, D Hella ${ }^{1}$, \\ F Blaffart ${ }^{1}$, P Kolh ${ }^{1,2}$, J-O Defraigne ${ }^{1,2}$, B Lambermont ${ }^{1,2}$ \\ From ESICM LIVES 2014 \\ Barcelona, Spain. 27 September - 1 October 2014
}

\section{Introduction}

Acute respiratory distress syndrome (ARDS) is responsible for injuries to the alveolar epithelium and microvascular endothelium resulting in hypoxemia, decreased pulmonary compliance and increased pulmonary vascular resistance. Beneficial effects resulting from protective lung ventilation are counterbalanced by deleterious hemodynamic effects. Indeed, hypercapnia resulting from ventilation at lower tidal volume enhances pulmonary hypertension and is associated with right ventricular failure in ARDS[1].

\section{Objectives}

The aim of our study was to determine if low flow $\mathrm{CO} 2$ removal therapy used at early stage of ARDS could have beneficial hemodynamic effects on pulmonary circulation.

\section{Methods}

This study was performed on an experimental model of ARDS obtained in 6 pigs. After sedation, analgesia and endotracheal intubation via a cervical tracheostomy, the pigs were connected to a volume-cycled ventilator. A micromanometer-tipped catheter was inserted into the main pulmonary artery and into the left atrium. Systemic arterial blood pressure (AP) was monitored via a micromanometer-tipped catheter inserted into the abdominal aorta through the left femoral artery. A conductance micromanometer-tipped catheter was inserted into the right ventricle. ARDS was obtained by repeated bronchoalveolar lavage ( $0.9 \%$ saline solution). Protective ventilation at lower tidal volume was then achieved.

${ }^{1}$ University Hospital of Liege, Liege, Belgium

Full list of author information is available at the end of the article
$12 \mathrm{Fr}$ aspiration and $10 \mathrm{Fr}$ injection cannulas were inserted into the inferior and the superior vena cava, respectively. These cannulas were connected to a pumpdriven extracorporeal membrane oxygenator (PALP, MAQUET, Germany) in order to achieve $\mathrm{CO} 2$ removal therapy.

\section{Results}

ARDS induced severe hypercapnic acidosis $(\mathrm{PaCO} 2=$ $82.5 \pm 10.8$ vs. $46.3 \pm 10.7 \mathrm{~mm} \mathrm{Hg}$ and $\mathrm{pH}=7.14 \pm 0.07$ vs. $7.46 \pm 0.07, \mathrm{p}<0.01)$. Systolic pulmonary artery pressure (PAPs) significantly increased from $27.4 \pm 4.3$ to $43.0 \mathrm{~mm} \mathrm{Hg}, \mathrm{p}<0.01$. After the PALP was started, acidosis was corrected $(\mathrm{pH}=7.39 \pm 0.08)$ and normocarbia was maintained $(\mathrm{PaCO} 2=41.9 \pm 12.6 \mathrm{~mm} \mathrm{Hg}, \mathrm{p}<0.01)$ despite protective ventilation (tidal volume $=6$ vs. $10 \mathrm{~mL} / \mathrm{kg}$ ). At the same time, PAPs significantly decreased to $30.8 \pm 5.0 \mathrm{~mm} \mathrm{Hg}, \mathrm{p}<0.01$. Cardiac output, left atrial pressure as well as AP did not significantly change. Mean PALP blood flow was $645 \mathrm{~mL} / \mathrm{min}$.

\section{Conclusions}

Veno-venous removal therapy enabled protective ventilation while maintaining normocarbia during ARDS. $\mathrm{CO} 2$ removal decreased pulmonary hypertension and improved right ventricular function. This technique may be an effective lung- and right ventricular-protective adjunct to mechanical ventilation.

\section{Grant acknowledgment}

Leon Fredericq Foundation.

\section{Authors' details}

${ }^{1}$ University Hospital of Liege, Liege, Belgium. ${ }^{2}$ University of Liege, GIGAResearch, Cardiovascular Sciences, Liege, Belgium. c 2014 Morimont et al; licensee Springer. This is an Open Access article distributed under the terms of the Creative Commons Attribution License (http://creativecommons.org/licenses/by/2.0), which permits unrestricted use, distribution, and reproduction in any medium, provided the original work is properly cited. 


\section{Reference}

1. Lheritier G, Legras A, Caille A, Lherm T, Mathonnet A, Frat JP, et al:

Prevalence and prognostic value of acute cor pulmonale and patent foramen ovale in ventilated patients with early acute respiratory distress syndrome: a multicenter study. Intensive Care Med 2013, 39:1734-42.

doi:10.1186/2197-425X-2-S1-P45

Cite this article as: Morimont et al:: 0681. Effects of veno-venous co2 removal therapy on pulmonary circulation in an ARDS model. Intensive Care Medicine Experimental 2014 2(Suppl 1):P45.

\section{Submit your manuscript to a SpringerOpen ${ }^{\circ}$ journal and benefit from:}

- Convenient online submission

- Rigorous peer review

- Immediate publication on acceptance

- Open access: articles freely available online

- High visibility within the field

- Retaining the copyright to your article

Submit your next manuscript at $\gg$ springeropen.com 